\title{
PENGGUNAAN PERMAINAN BALOK DALAM MENINGKATKAN KREATIVITAS ANAK USIA 5-6 TAHUN DI TK AL KAUSAR
}

\author{
Isnanizar Tanjung
}

Guru TK Al-Kausar

Surel : tanjung.isnanizar@gmail.com

\begin{abstract}
ABSTRAK
Penelitian ini bertujuan untuk mengetahui peningkatan kreativitas anak usia 5-6 tahun melalui metode proyek di TK Pertiwi-I Medan. Hasil observasi dan refleksi pada siklus I setelah melaksanakan permainan balok dalam proses pembelajaran diketahui bahwa dari 15 anak, 3 orang anak (20\%) tergolong sangat baik, 7 orang anak (47\%) tergolong baik, dan 5 orang anak $(33 \%)$ tergolong cukup baik. Nilai rata - rata kreativitas anak yaitu 66. Pada siklus ini kemampuan klasikal belum tercapai karena kemampuan klasikal anak pada kriteria baik (60-79) lebih rendah dari $75 \%$ yaitu $67 \%$. Pada siklus II setelah dilakukan perbaikan cara penyampaian pembelajaran dalam permainan balok, maka diketahui bahwa peningkatan kreativitas anak meningkat yaitu 8 orang anak (53\%) yang memiliki kreativitas sangat baik, 5 orang anak (33\%) baik dan 2 orang anak (14\%) cukup baik. Nilai rata-rata kreativitas anak yaitu 81. Pada siklus ini kemampuan klasikal anak sudah tercapai yaitu sebesar $86 \%$.
\end{abstract}

Kata Kunci : Permainan balok, Kreativitas, Anak

\section{PENDAHULUAN}

Setiap orang memiliki kemampuan kreatif, dan kreativitas bisa diajarkan dan dipelajari. Sebagian orang lain berpendapat bahwa kreativitas selalu dimiliki oleh orang berkemampuan akademik yang tinggi. Namun faktanya, banyak orang yang memiliki kemampuan akademis tinggi tetapi tidak otomatis melakukan aktivitas yang menghasilkan output kreatif. Kreativitas sangat penting dalam proses belajar, sebab keberhasilan anak didik dalam belajar sangat tergantung pada kreativitasnya. Proses belajar mengajar akan berlangsung sangat menyenangkan bila terjadi kegiatan belajar yang kreatif. Dimana anak didik memiliki hasrat ingin tahu yang mendalam tentang masalah yang dihadapi dengan cara mencari jawaban dari informasi yang lebih luas lagi.

Keinginan anak untuk meningkatkan kreativitas menjadikan anak aktif dan eksploratif. Dalam berkreativitas seluruh panca indera anak terlibat untuk memahami sesuatu dan dalam waktu singkat anak beralih ke hal lain untuk dipelajari. Lingkunganlah yang terkadang menjadi penghambat dalam meningkatkan kemampuan kreativitas anak dan sering kali lingkungan mematikan keinginan anak untuk bereksplorasi.

Menurut Aqib

(2008:35)

kreativitas merupakan kemampuan seseorang untuk melahirkan sesuatu yang baru atau relatif baru, baik berupa gagasan maupun karya nyata 
yang relatif berbeda dengan apa yang telah ada sebelumnya. Sementara itu, Moreno (dalam Slameto 2010:146) mengatakan bahwa "kreativitas bukalah penemuan sesuatu yang belum diketahui orang sebelumnya, melainkan produk kreativitas itu merupakan sesuatu yang baru bagi diri sendiri dan tidak merupakan sesuatu yang baru bagi orang pada umumnya." Kreativitas menurut Lumsdaine (2010:1) adalah mempergunakan imajinasi dan berbagai kemungkinan yang diperoleh dari interaksi dengan ide atau gagasan, orang lain dan lingkungan untuk membuat koneksi dan hasil yang baru serta bermakna.

Dari pendapat di atas maka dapat disimpulkan bahwa kreativitas merupakan kemampuan sesorang dalam mempergunakan imajinasi untuk melahirkan sesuatu yang baru atau relatif baru, baik berupa gagasan maupun karya nyata yang relatif berbeda dengan apa yang telah ada sebelumnya. Artinya kreativitas merupakan hasil interaksi individu dengan lingkungannya. Dan bukan semata-mata hanya dimiliki oleh orang-orang yang berintelegensi tinggi.

Dalam meningkatkan kreativitas anak perlu digunakan cara - cara tertentu agar kreativitas tersebut dapat berkembang dalam diri anak. Setiap anak lahir dengan potensi kreatif, dan potensi ini harus dikembangkan dan dipupuk. Namun, pada kenyataannya kreativitas anak di TK Al Kausar Jl. Gurilla No. 107 Medan masih tergolong rendah. Hal ini disebabkan karena metode mengajar yang digunakan guru kurang tepat dalam meningkatkan kreativitas anak. Ketika mengajar umumnya guru masih mengutamakan metode ceramah, dan mengutamakan kegiatan bermain dari pada belajar. Sehingga waktu anak lebih banyak dihabiskan oleh kegiatan guru dan kegiatan bermain. Tak jarang guru membiarkan anak bermain-main sampai jam belajar habis.

Selain itu, rendanya kreativitas anak didik disebabkan kurangnya perhatian orang tua untuk mengembangkan kreativitas anak. Orang tua umumnya akan merasa bangga bila anak didiknya mampu membaca dan berhitung dangan lancar sehingga nilai moral dan emosi tak lagi penting. Tuntutan orang tua dan syarat untuk memasuki jenjang pendidikan yang lebih tinggi menjadi dalih yang menghendaki anak pandai membaca dan berhitung. Seorang guru hanya menekankan metode yang mengasah kecerdasan otak kiri saja yaitu membaca dan berhitung. Penggunaan metode yang statis membuat anak bosan akibatnya otak kanan yang berfungsi sebagai pengembangan kreativitas anak tidak berkembang secara optimal.

Rendahnya kreativitas belajar anak juga disebabkan karena rendahnya motivasi belajar dari dalam diri anak tersebut. Kreativitas akan berkembang bila dibarengi motivasi anak untuk berkreasi. Tetapi hal ini tidak terlihat pada diri anakanak TK Alkausar. Hal ini disebabkan karena sarana dan 
prasarana untuk mendukung aktivitas dalam meningkatkan kreativitas anak tidak tampak. Guru hanya mengutamakan penggunaan bukubuku, pensil, kertas dalam pembelajaran. Sementara sarana untuk menumbuhkan dan mengembangkan daya kreativitas tidak tampak. Motivasi untuk menggambar akan menghasilkan gambar yang menarik dan memiliki karya seni yang bernilai tinggi.

Melihat banyaknya faktor yang mempengaruhi kreativitas belajar anak, maka salah faktor yang diperkirakan memiliki hubungan yang erat dengan kreativitas anak yaitu melalui permainan balok. Balok adalah media yang hampir mempunyai variasi yang lengkap (tidak terhitung) sebagai alat permainan yang dapat menunjang perkembangan kognitif anak. Melalui penggunaan balok anak dapat melatih keterampilan motorik halusnya, berlatih untuk memecahkan masalah, bebas berimajinasi, dan menciptakan hal-hal baru sebagai sebuah ide kreatif.

Alat permainan edukatif merupakan media yang tidak terpisahkan dalam pembelajaran anak di TK. Ketersediaan alat permainan tersebut menunjang terselenggaranya pembelajaran anak secara efektif dan menyenangkan sehingga anak-anak dapat mengembangkan berbagai potensi yang dimilikinya secara optimal. Balok adalah jenis mainan yang dapat digunakan untuk membuat bangunan rumah-rumahan, jembatan, mobil-mobilan dan lain- lain. Setiap model membutuhkan kemampuan untuk menemukan potongan atau kepingan balok-balok yang tepat untuk disusun, baik ukuran maupun bentuknya serta cara mengerjakan yang terbaik didalam memasang - masangkannya. Setelah anak semakin tumbuh kepercayaan dirinya, ia mulai dapat memikirkan tentang penggunaan warna dan kesesuaiannya untuk menciptakan model - model ciptaannya sendiri.

Heruman

(2007:167)

mengatakan bahwa balok adalah suatu bangun ruang dimana setiap sisinya berbentuk persegi panjang memiliki tiga pasang sisi berhadapan yang sama bentuk dan ukurannya. Sementara itu, Subroto (2009:140) bahwa balok adalah suatu bangun ruang yang dibatasi oleh enam sisi aau tiga pasang sisi berbentuk persegi panjang. Sedangkan menurut Negoro dan Harahap (2002:20) menjelaskan bahwa balok adalah suatu bangun ruang. Balok adalah potonganpotongan kayu yang polos (tanpa dicat), sama tebalnya dan dengan panjang dua kali atau empat kali sama besarnya dengan satu unit balok. Sedikit berbentuk kurva, silinder dan setengah dari potonganpotongan balok juga disediakan, tetapi semua dengan panjang yang sama yang sesuai dengan ukuran balok-balok dasar.

Balok adalah jenis mainan membuat bangunan rumah-rumahan, jembatan, mobil-mobilan dan lainlain. Setiap model membutuhkan kemampuan untuk menemukan 
potongan atau kepingan balok-balok yang tepat untuk disusun, baik ukuran maupun bentuknya serta cara mengerjakan yang terbaik didalam memasang-masangkannya. Setelah anak semakin tumbuh kepercayaan dirinya, ia mulai dapat memikirkan tentang penggunaan warna dan kesesuaiannya untuk menciptakan model-model ciptaanya sendiri.

Maka, dapat disimpulkan bahwa permainan balok adalah suatu kegiatan yang menggunakan jenis mainan berupa bangun ruang yang dibatasi oleh enam sisi aau tiga pasang sisi berbentuk persegi panjang memberikan kesenangan dan dapat mengembangkan imajinasi anak

Berdasarkan latar belakang masalah, dapat dikaji ada beberapa permasalahan yang dirumuskan sebagai berikut: Apakah dengan menggunakan permainan balok dapat meningkatkan kreativitas anak usia 5-6 tahun di TK Al Kausar Tahun Ajaran 2014/2015?

Merujuk pada rumusan masalah di atas, maka tujuan dilaksanakan penelitian ini adalah untuk meningkatkan kreativitas anak usia 5-6 tahun dengan menggunakan permainan balok di TK Al Kausar Tahun Ajaran 2014/2015.

\section{METODE PENELITIAN}

\section{Tempat dan Waktu Penelitian}

Penelitian ini dilaksanakan di kelompok B di TK Alkausar Jl. Gurilla No. 107 Medan. Penelitian ini dilaksanakan selama 4 Bulan (September 2014 s/d Desember
2014) mulai dari persiapan hingga pelaksanaan tindakan.

\section{Subjek Penelitian}

Subjek dalam penelitian tindakan kelas ini adalah anak di kelompok B TK Alkausar berjumlah 15 orang, yang terdiri dari 9 anak laki-laki dan 6 anak perempuan.

\section{Alat Pengumpul Data}

Alat pengumpulan data yang digunakan dalam penelitian ini adalah lembar observasi tentang kreativitas anak selama kegiatan pembelajaran berlangsung.

\section{Tabel Kisi-Kisi Perkembangan}

\section{Kreativitas Anak}

\begin{tabular}{|c|c|c|}
\hline No & Indikator & Deskriptor \\
\hline 1 & Penuh energi & $\begin{array}{ll}\text { a. } & \text { Siap bila diunjuk } \\
\text { b. } & \text { Gemar bertanya } \\
\text { c. } & \text { Memiliki } \\
& \text { semangat belajar } \\
\text { d. } & \text { Senang } \\
& \text { mengamati }\end{array}$ \\
\hline 2 & $\begin{array}{l}\text { Mempunyai } \\
\text { prakarsa } \\
\text { imajinatif }\end{array}$ & $\begin{array}{ll}\text { a. } & \text { Memiliki inisiatif } \\
\text { dalam belajar } \\
\text { b. Dapat } \\
\text { memberikan } \\
\text { gagasan } \\
\text { c. Tidak banyak } \\
\text { bicara } \\
\text { d. Dapat mengambil } \\
\text { keputusan dengan } \\
\text { tepat }\end{array}$ \\
\hline 3 & Percaya diri & 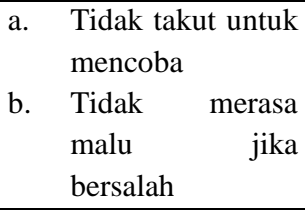 \\
\hline 4 & $\begin{array}{l}\text { Ulet } \\
\text { mengerjakan } \\
\text { tugas }\end{array}$ & $\begin{array}{ll}\text { a. } & \text { Belajar dengan } \\
\text { sungguh-sungguh } \\
\text { b. Mengulang } \\
\text { pelajaran yang } \\
\text { telah dipelajari }\end{array}$ \\
\hline
\end{tabular}




\section{Desain Penelitian}

Penelitian ini menggunakan desain model Kemmis dan Mc. Taggart (dalam Rosmala Dewi, 2010:122). Penelitian ini dilakukan dengan 2 siklus, yakni siklus I dan siklus II, yang terdiri dari empat komponen yaitu: 1. Perencanaan, 2. Tindakan, 3. Pengamatan, 4. Refleksi.

\section{Teknik Analisis Data}

Analisa ini dilakukan untuk mengetahui berhasil atau tidaknya tindakan yang dilakukan dalam penelitian ini. Hal ini di lihat dari seberapa persenkah tingkat keberhasilan yang akan diperoleh.

Analisis lembar observasi untuk mengetahui peningkatan kreativitas anak. Hasil observasi dianalisis dengan menggunakan analisis presentase. Analisis presentase dengan menggunakan rumus sebagaimana yang disampaikan Sugiono (dalam Tarigan. 2011) yaitu :

$$
P i=\frac{f}{\mathrm{n}} \mathrm{x} 100
$$

Dimana :

$$
\begin{aligned}
& \mathrm{Pi}=\text { Hasil Pengamatan } \\
& \mathrm{f}=\text { Jumlah skor yang dicapai } \\
& \quad \text { anak } \\
& \mathrm{n}=\text { Jumlah skor total }
\end{aligned}
$$

Dimana kriteria penilaian yang digunakan menurut Aqib (2009:41) yaitu :
Tabel Kriteria Penilaian

\begin{tabular}{|c|c|}
\hline Prestasi & Keterangan \\
\hline $80 \%-100 \%$ & Sangat baik \\
$60 \%-79 \%$ & Baik \\
$30 \%-59 \%$ & Cukup \\
$10 \%-29 \%$ & Kurang \\
\hline
\end{tabular}

\section{HASIL PENELITIAN DAN PEMBAHASAN}

\section{Hasil dan Pembahasan Siklus I}

\section{a. Perencanaan Siklus I}

Sebelum melakukan tindakan siklus I, peneliti telah menyusun perencanaan pembelajaran yang akan dilaksanakan di dalam kelas, antara lain:

1. Guru dan peneliti secara kolaboratif merencanakan pembelajaran.

2. Peneliti membuat rencana pelaksanaan kegiatan.

3. Menyusun Rencana Kegiatan Harian (RKH).

4. Mempersiapkan bahan/media yang akan digunakan pada kegiatan pembelajaran.

5. Membuat lembar observasi

\section{b. Tahap Pelaksanaan Siklus I}

Pada tahap ini kegiatan yang akan dilakukan adalah melaksanakan penelitian sesuai dengan rencana penelitian dengan mengutamakan tindakan yang akan dilaksanakan yaitu meningkatkan kreativitas anak usia 5-6 tahun melalui permainan balok.

I. Kegiatan Awal

- Salam pembuka

- Berdoa nyanyi 
- Pertemuan pagi

- Penyampaian materi pembelajaran

II. Kegiatan Inti

- Guru memperkenalkan alat dan bahan yang akan digunakan oleh anak.

- Guru membagi bahan dan peralatan (balok dan media lain) untuk kegiatan pembelajaran kepada masingmasing anak.

- Guru membimbing dan mengarahkan anak sewaktu kegiatan berlangsung.

III. Istirahat/ Makan

IV. Kegiatan Akhir

- Diskusi kegiatan hari ini.

- Bernyanyi

- Berdoa dan salam.

\section{c. Hasil Pengamatan Siklus I}

Selama proses pembelajaran dengan permainan balok, peneliti di bantu oleh guru selaku mitra kolaborasi untuk mengamati seluruh aktivitas atau kegiatan yang terjadi dengan menggunakan lembar observasi yang telah disiapkan oleh peneliti. Hasil pengamatan guru tersebut, menunjukkan bahwa aktivitas peneliti selaku guru selama tindakan pada siklus I pada aspek penyediaan peralatan (permainan balok), menjelaskan tujuan dengan menggunakan gambar media, menjelaskan tentang permainan balok, mengapresiasikan hasil karya dan pendapat anak, serta memberikan respon terhadap hasil karya dan pendapat anak ke dalam kategori baik.
Selama proses pembelajaran meningkatkan kreativitas anak dengan permainan balok, peneliti mengamati aktivitas anak dengan menggunakan lembar observasi yang telah dipersiapkan. Pelaksanaan penelitian dilakukan oleh peneliti dan dibantu oleh guru kelas. Dari hasil pengamatan yang dilakukan pada siklus I dengan dua kali pertemuan, diketahui bahwa tindakan yang dilakukan peneliti belum optimal dalam meningkatkan kreativitas anak. Ini terlihat pada tabel berikut:

Tabel Hasil Pengamatan Peningkatan Kreativitas Anak Selama Siklus I

\begin{tabular}{|c|c|c|c|c|}
\hline No. & Skor & $\mathrm{N}$ & $\%$ & Keterangan \\
\hline 1. & $80-100$ & 3 & 20 & Sangat Baik \\
\hline 2. & $60-79$ & 7 & 47 & Baik \\
\hline 3. & $30-59$ & 5 & 33 & Cukup Baik \\
\hline 4. & $10-29$ & 0 & 0 & $\begin{array}{l}\text { Kurang } \\
\text { Baik }\end{array}$ \\
\hline \multicolumn{2}{|c|}{ Jumlah } & 15 & 100 & \\
\hline
\end{tabular}

Berdasarkan hasil pengamatan pada Siklus I Pertemuan II, peneliti melihat bahwa peningkatan kreativitas anak belum meningkat dan masih cenderung rendah. Tabel 4.2. di atas menunjukkan bahwa pada siklus I, peningkatan kreativitas anak sebagai berikut: $20 \%$ tergolong sangat baik, $47 \%$ tergolong baik, dan $33 \%$ tergolong cukup baik.

\section{c. Refleksi Siklus I}

Berdasarkan hasil observasi yang telah dilakukan selama siklus I dapat dilihat bahwa melalui permainan balok, belum dapat meningkatkan kreativitas anak secara 
optimal. Dimana pada siklus I, peningkatan kreativitas anak masih tergolong rendah.

Berdasarkan hasil observasi pada siklus I, analisis penyebab utama yaitu:

1. Masih terdapat anak yang belum mampu berkreativitas dengan balok-balok.

2. Masih terdapat anak yang belum mampu membuat bangunan dari balok berbentuk lingkaran segi tiga jajaran genjang, persegi panjang.

3. Dalam penyampaian penjelasan penggunaan permainan balok peneliti harus lebih memperhatikan apakah anak sudah paham dengan penjelasan peneliti tentang cara penggunaan balok sebagai media yang dapat meningkatkan kreativitas anak.

4. Peneliti lebih memperhatikan dan memotivasi anak.

Peneliti menyajikan permainan balok yang lebih menarik dari media permainan sebelumnya untuk menarik perhatian.

\section{Hasil dan Pembahasan Siklus II}

\section{a. Perencanaan Siklus II}

Berdasarkan hasil refleksi Siklus I yang telah dilaksanakan selama dua kali pertemuan, maka di peroleh hasil bahwa peningkatan kreativitas anak masih tergolong rendah, untuk itu penelitian ini dilanjutkan ke siklus II. Tahap perencanaan siklus II meliputi kegiatan:
1. Guru dan peneliti secara kolaboratif merencanakan pembelajaran.

2. Peneliti membuat rencana pelaksanaan kegiatan.

3. Menyusun Rencana Kegiatan Harian (RKH).

4. Mempersiapkan bahan/media yang akan digunakan pada kegiatan pembelajaran.

5. Membuat lembar observasi

\section{b. Pelaksanaan Siklus II}

Pelaksanaan tindakan siklus II dilaksanakan selama dua kali pertemuan. Pada kegiatan ini, yang dilaksanakan adalah berupa perbaikan dari siklus I.

I. Kegiatan Awal

- Salam pembuka

- Berdoa nyanyi

- Pertemuan pagi

- Penyampaian materi pembelajaran

II. Kegiatan Inti

- Guru memperkenalkan alat dan bahan yang akan digunakan oleh anak.

- Guru membagi bahan dan peralatan (balok dan media lain) untuk kegiatan pembelajaran kepada masingmasing anak.

- Guru membimbing dan mengarahkan anak sewaktu kegiatan berlangsung.

III. Istirahat/ Makan

IV. Kegiatan Akhir

- Diskusi kegiatan hari ini.

- Bernyanyi 
- Berdoa dan salam.

\section{c. Hasil Pengamatan Siklus II}

Hasil observasi yang dilakukan oleh peneliti dan guru di TK Alkausar Medan, menunjukkan bahwa aktivitas peneliti selaku guru selama tindakan siklus II pada aspek penyediaan peralatan (permainan balok), menjelaskan tujuan kegiatan dengan menggunakan media, menjelaskan tentang permainan balok dan menjelaskan cara - cara permainan balok, mengapresiasikan hasil karya anak, serta memberikan respon terhadap hasil karya anak tergolong ke dalam kategori sangat baik.

Selama proses pembelajaran pada permainan balok, peneliti dan observer sebagai mitra kolaborasi ikut secara bersama-sama mengamati aktivitas anak pada siklus ke II dan mengisi lembar observasi yang telah disediakan. Secara ringkas, hasil pengamatan peningkatan kreativitas anak selama siklus II disajikan pada tabel berikut ini:

Tabel Hasil Pengamatan Peningkatan Kreativitas Anak Pada Siklus II

\begin{tabular}{|c|c|c|c|c|}
\hline No. & Skor & $\mathrm{N}$ & $\%$ & Keterangan \\
\hline 1. & $80-100$ & 8 & 53 & $\begin{array}{l}\text { Sangat } \\
\text { Baik }\end{array}$ \\
\hline 2. & 60-79 & 5 & 33 & Baik \\
\hline 3. & $30-59$ & 2 & 14 & $\begin{array}{l}\text { Cukup } \\
\text { Baik }\end{array}$ \\
\hline 4. & $10-29$ & 0 & 0 & $\begin{array}{l}\text { Kurang } \\
\text { Baik }\end{array}$ \\
\hline \multicolumn{2}{|c|}{ Jumlah } & 15 & 100 & \\
\hline
\end{tabular}

Tabel di atas, menunjukkan bahwa hingga pertemuan kedua pada siklus II, peningkatan kreativitas anak berada pada kategori: 53\% sangat baik, $33 \%$ baik dan 14\% cukup baik.

\section{d. Refleksi Siklus II}

Berdasarkan hasil observasi yang dilakukan oleh guru pendamping selaku mitra kolaborasi, di peroleh bahwa aktivitas yang dilakukan peneliti selama melaksanakan tindakan siklus II sudah tergolong baik.

Selanjutnya hasil observasi yang telah dilakukan selama siklus II dapat dilihat bahwa melalui permainan balok dapat meningkatkan kreativitas anak. Dimana pada pertemuan kedua siklus II, peningkatan kreativitas anak sudah tergolong dalam kategori baik. Hal ini tampak dari hasil observasi yang dilakukan, yaitu 53\% dikategorikan sangat baik, 33\% baik, serta 14\% cukup baik. Setelah dilakukan analisis dan refleksi siklus II, diperoleh kesimpulan bahwa permainan balok dapat meningkatkan kreativitas anak 5-6 Tahun di TK Alkausar.

\section{Pembahasan Penelitian}

Permainan balok yang dilaksanakan di kelompok B pada anak usia 5-6 tahun di TK Alkausar merupakan penelitian tindakan yang bertujuan untuk meningkatkan kreativitas anak. Penelitian ini dilaksanakan selama dua kali siklus, 
masing-masing siklus dilaksanakan dua kali pertemuan.

Permainan balok terbukti dapat meningkatkan kreativitas anak. Anak dapat berkreasi membuat berbagai bentuk bangunan dari balok-balok yang disediakan dan peningkatan kreativitas anak pada permainan balok hingga akhir pertemuan setiap siklus secara ringkas dirangkum pada tabel berikut ini:

Tabel Rangkuman Peningkatan Kreativitas Anak Pada Siklus I dan II

\begin{tabular}{|l|l|l|l|l|l|l|}
\hline \multirow{2}{*}{ No } & \multirow{2}{*}{ Skor } & \multirow{2}{*}{ Kriteria } & \multicolumn{2}{|l|}{ Siklus I } & \multicolumn{2}{|c|}{ Siklus II } \\
\cline { 4 - 7 } 1 & $80-100$ & $\begin{array}{l}\text { Sangat } \\
\text { Baik }\end{array}$ & 3 & 20 & 8 & 53 \\
\hline 2 & $60-79$ & Baik & 7 & 47 & 5 & 33 \\
\hline 3 & $30-59$ & $\begin{array}{l}\text { Cukup } \\
\text { Baik }\end{array}$ & 5 & 33 & 2 & 14 \\
\hline 4 & $10-29$ & $\begin{array}{l}\text { Kurang } \\
\text { Baik }\end{array}$ & 0 & 0 & 0 & 0 \\
\hline 5 & \multicolumn{2}{|c|}{ Jumlah } & & 15 & $\begin{array}{l}10 \\
0\end{array}$ & $\begin{array}{l}1 \\
5\end{array}$ \\
\hline
\end{tabular}

Dari tabel di atas, dapat diketahui bahwa kreativitas anak hingga akhir pertemuan siklus I 20\% tergolong sangat baik, $47 \%$ tergolong baik, dan 33\% tergolong cukup baik. Hal ini berarti bahwa permainan balok yang dilakukan pada siklus I dapat meningkatkan kreativitas anak, namun masih kurang optimal. Dengan demikian, perlu dilakukan tindakan yang lebih baik pada siklus II. Pada siklus II dilakukan perbaikan pembelajaran dengan tetap melaksanakan permainan balok.

Pada siklus II ini, peneliti perlu memperbaiki penyampaian penjelasan pada permainan balok, dan juga memperhatikan apakah anak sudah paham dengan penjelasan tentang cara permainan balok tersebut. Selain itu, pada siklus II ini peneliti juga harus lebih memperhatikan dan memotivasi anak dalam mengerjakan tugas yang diberikan serta membuat bentuk yang lebih menarik dari bentuk bangunan sebelumnya sehingga anak lebih tertarik untuk mengikuti permainan balok. Setelah dilakukan tindakan pada siklus II, menunjukkan adanya peningkatan kreativitas anak dibandingkan pada siklus II, yaitu bahwa 53\% sangat baik, 33\% baik dan $14 \%$ cukup baik.

Berdasarkan hasil penelitian dan observasi yang dilakukan hingga siklus II, menunjukkan adanya peningkatan kreativitas anak. Temuan yang diperoleh melalui permainan balok, antara lain:

1. Melalui permainan balok dapat meningkatkan kreativitas anak. Hal ini terlihat dari meningkatnya persentase indikator kreativitas anak.

2. Melalui permainan balok dapat melatih anak dalam meningkatkan kreativitas anak sesuai dengan keinginan anak masing - masing dalam menciptakan bentuk yang diinginkan anak.

3. Keberhasilan dalam memberikan rangsangan kepada anak dalam proses pembelajaran agar kreativitas anak melalui permainan balok ini dapat meningkatkan dengan memberikan penguatan serta 
pujian kepada anak supaya anak lebih bersemangat dalam bermain sambil belajar

Kreativitas anak dapat meningkat melalui permainan balok, karena melalui permainan balok, pembelajaran lebih menyenangkan, dimana ketika proses pembelajaran berlangsung anak dapat berkreasi menciptakan sesuatu dengan balok yang telah disediakan. Selain itu, melalui permainan balok kegiatan pembelajaran lebih menarik bagi anak.

\section{KESIMPULAN}

Berdasarkan hasil penelitian dan analisis data, dapat disimpulkan sebagai berikut :

a. Permainan balok pada pembelajaran dapat meningkatkan anak usia 5-6 tahun di TK Alkausar Medan.

b. Peningkatan kreativitas anak pada siklus I diperoleh kreativitas anak masih rendah. Dari 15 anak, 3 orang anak (20\%) tergolong sangat baik, 7 orang anak (47\%) tergolong baik, dan 5 orang anak (33\%) tergolong cukup baik. Nilai rata rata kreativitas anak yaitu 66 . Pada siklus ini kemampuan klasikal belum tercapai karena kemampuan klasikal anak pada kriteria baik (60-79) lebih rendah dari $75 \%$ yaitu $67 \%$.

c. Pada siklus II terjadi peningkatan yang signifikan, 8 orang anak (53\%) yang memiliki kreativitas sangat baik, 5 orang anak (33\%) baik dan 2 orang anak (14\%) cukup baik. Nilai rata - rata kreativitas anak yaitu 81. Pada siklus ini kemampuan klasikal anak sudah tercapai yaitu sebesar $86 \%$.

Dari kesimpulan diatas, maka saran - saran yang dapat diberikan yaitu:

a. Dalam kegiatan pembelajaran khususnya meningkatkan kreativitas anak diharapkan guru dapat menggunakan permainan, salah satunya dengan menggunakan permainan balok.

b. Stimulus diberikan agar anak semangat dalam melakukan permainan yang diberikan.

c. Untuk guru pendidikan anak usia dini diharapkan lebih kreatif dan inovatif dalam pembelajaran sehingga anak tidak merasakan kejenuhan saat pembelajaran.

d. Kepada peneliti yang akan melakukan penelitian sejenis diharapkan mampu mempersiapkan penelitian dengan matang sehingga hasil penelitian yang didapatkan lebih baik lagi.

\section{DAFTAR RUJUKAN}

Aqib. Zainal. 2011. Penelitian Tindakan Kelas. Bandung: Yrama Widya.

Dewi, Rosmala. 2005. Berbagai Masalah Anak Taman Kanak-Kanak. Jakarta: Depdiknas

Heruman. 2007. Model Pembelajaran Matematika Di Sekolah Dasar. Bandung: Remaja Rosda Karya. 
Isnanizar Tanjung. 2014.

Peningkatan Kreativitas

Anak Usia 5-6 Tahun

Melalui Permainan Balok Di

TK Al Kausar Tahun Ajaran

2014/2015. Medan

Negoro, dan Harahap. B. 2002.

Ensiklopedia Matematika.

Jakarta: Ghalia Indonesia.

Slameto. 2010. Belajar dan Faktor-

Faktor Yang Mempengaruhi.

Jakarta:Rineka Cipta.

Tarigan Irfiani. 2011. Meningkatkan

Keterampilan Melipat

Dengan Memanfaatkan

Kertas Bekas Melalui

Metode Demonstrasi Pada

Mata Pelajaran SBK Di

Kelas 4 SD Negeri 043935

Kabanjahe. Skripsi. FIP.

Unimed. 